ACTA THERIOLOGICA

Vol. 23, 24: $381-390,1978$

\title{
The Activity Pattern in White-Toothed Shrews Studied With Radar
}

\author{
GILLIAN K. GODFREY \\ (Mrs Crowcroft)
}

\begin{abstract}
Godfrey G. K., 1978: The activity pattern in white-toothed shrews studied with radar. Acta theriol., 23, 24: 381-390 [With 3 Tables \& 3 Figs.] Total activity in the white-toothed shrews, Crocidura suaveolens $\mathrm{P}$ a $1 \mathrm{las}, 1811$ and C. russula $\mathrm{H}$ e r $\mathrm{mann}, 1870$, was detected by radar. Individuals were found to be active throughout the 24 hours with russula being the more diurnal speoies. The activity patterns of newlytrapped shrews showed well-marked feeding rhythms with mean cyclelengths of $30-50$ minutes. $F_{1}$ Crocidura were more diurnal than newlytrapped animals, and their activity patterns showed neither a feeding nor a 24-hour rhythm.

[The Wildlife Park, Jersey, Channel Islands].
\end{abstract}

\section{INTRODUCTION}

In a classic study on activity patterns in British shrews, $\mathrm{C} r$ o w c r of $\mathrm{t}$ (1954) detected a short-term rhythm with a periodicity of about two hours and a longer, 24-hour or circadian rhythm. The common shrew (Sorex araneus) had ith major peak of activity at night while in the single pygmy shrew (S. minutus) studied, the major peak occurred during the day. Loxton et al. (1975) have since confirmed that the common shrew is more active at night. In the white-toothed shrews (Crocidura), our knowledge of activity is limited to 24 hours' observation of 3 captive individuals ( $\mathrm{R} \circ \mathrm{od}, 1965)$, and to data obtained while trapping ( $\mathrm{S}$ p e $\mathrm{n}$ c e r - B o t h, 1963; P e r n e t t a, 1973).

The present observations, made during $1975-76$, were on newlytrapped animals: Crocidura suaveolens $\mathrm{P}$ a 11 as, 1811 from the island of Jersey and C. russula $\mathrm{H}$ e r m a n n, 1870 from the island of Alderney. Activity patterns of shrews born in the laboratory were studied for comparison.

\section{METHOD OF STUDY}

The study was carried out in a room where ambient temperatures ranged from $4-12^{\circ} \mathrm{C}$. Most of the observations were made under natural light but one series -was made using an artificial photoperiod (12L:12D) with light from a $100 \mathrm{~W}$ bulb. 
The experimental animal was housed in a metal bin, $42 \mathrm{~cm}$ high and $58 \mathrm{~cm}$ in diameter, identical with those used for laboratory breeding. The bin was floored with $3-4 \mathrm{~cm}$ peat and topped with a $12-15 \mathrm{~cm}$ layer of fine paper strips to serve as cover. A metal nest-box was provided. Mealworms (Tenebrio sp.) in excess of the animal's requirements were supplied daily. Water for drinking was always present.

Activity was detected by radar. A solid-state $\mathrm{x}$-band Doppler radar module was mounted approximately $150 \mathrm{~cm}$ above the recording bin. The radar module transmits pulses of short-wave radiation in the form of a beam. Any object lying in the path of the beam reflects back these pulses which pass through an integrator and are relayed to a chart-recorder. Since the time-interval between the transmission of a pulse and the receipt of its echo varies directly with the distance from the target, activity can be detected by changes in signal frequency. The sensivity of the apparatus is readily adjusted by altering the distance between the radar module and the recording bin. Most of the signals received were, in fact, from the paper strips which were disturbed by the animal's movements.

It was possible to study periods of feeding activity while excluding other forms of activ:ty by placing aluminium foil, which is not penetrated by radar, over most of the bin. A hole $7 \mathrm{~cm}$ in diameter was cut in the foil, and beneath the hole the food-pot. was positioned.

The experimental animals consisted of C. suaveolens ( $\sigma^{*}+$ wt $\left.5.0-5.5 \mathrm{~g}\right)$; C. russula $\left(\sigma^{7}+\right.$ :wt $\left.9.0-9.5 \mathrm{~g}\right) ; \mathrm{F}_{1}$ C. suaveolens $\left(\sigma^{*}: 9.5 \mathrm{~g}\right)$ and $\mathrm{F}_{1}$ C. russula $\left(\sigma^{7} \circ: 9.0-\right.$ $-13.0 \mathrm{~g}$ ). Wild-trapped shrews were allowed in initial $2-3$ days to odjust to captivity before recording was begun. All the animals were sexually mature. Observations were made during the months March to July, and they normally lasted for 10 consecutive days.

\section{ANALYSIS OF RESULTS}

Records were obtained on a tape running at a speed of $6 \mathrm{~cm} / \mathrm{hour}$. Each $\mathrm{mm}$ of tape, representing one minute of recording time, was scored for the presence or absence of activity. Activity was summed for each 24-hour period (1440 minutes). This system of scoring, which was found to be a practical one for apparatus and data of this kind, introduces a slight error; however, the error is relatively unimportant when the unit of measurement is of the order of one minute (see C row croft, 1954; C r ow croft \& G odfrey, 1958).

When the feeding records were analysed it was found that the number of visits to the food-pot exceeded the number of mealworms consumed. Some of the surplus pen-strokes may have been due to "empty-handed " journeys; however, a group of pen-strokes suggests that the animal sat in the food-pot while eating instead of carrying the mealworms away. The finding of Tenebrio heads and tails in the food-pot confirmed this.

\subsection{The Activity Pattern in C. suaveolens}

When first brought into the laboratory C. suaveolens were far more 
active by night than by day (Fig. 1, a-b). Activity patterns were reasonably consistent throughout the 10 days and they were similar in the two individuals studied; the sudden cessation of activity in 999 (Fig. 1, a)
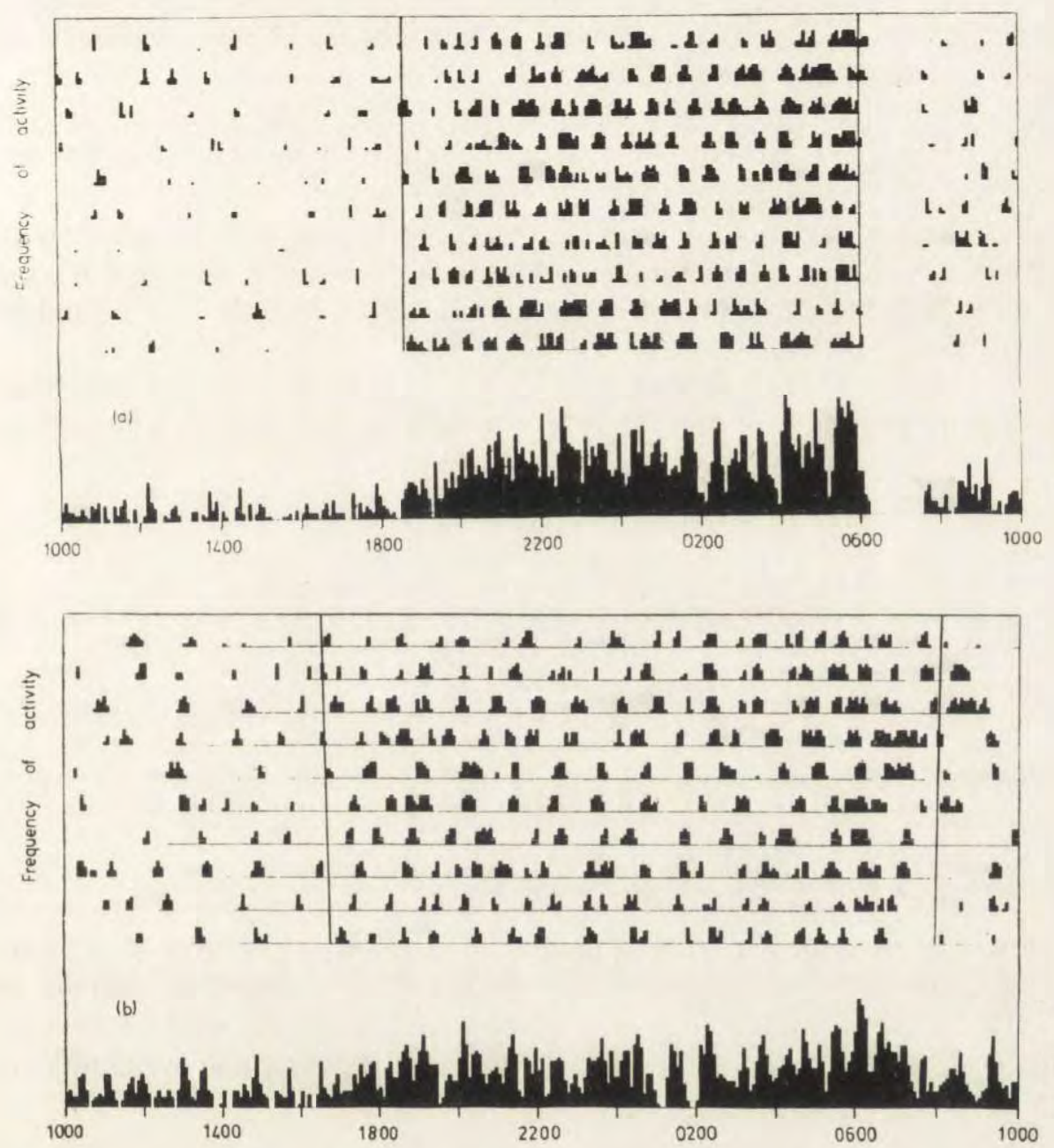

Fig. 1. Total activity recorded during 10 consecutive days (above) with summed records (below). Time (unit $=5^{\prime \prime}$ ) on $x$-axis, number of minutes activity (maximum of 5) on $y$-axis. Sunrise and sunset indicated by solid lines.

a, C. suaveolens, female 99 b, C. suaveolens, male 100

at 0600 hours was due to the absence of a dawn/dusk effect in the timeswitch mechanism. Records summed over 10 days show more activity soon after dusk and just before dawn than around midnight although 
these peaks of activity are less marked than those recorded in Sorex. A 24-hour rhythm is apparent.

Inspection of the individual records for nights reveals a number of short periods of activity separated by slightly longer periods of rest. Periodicity is obvious, and the mean cycle length, obtained by dividing the hours of darkness by the periods of activity, is 40 minutes for 999 and 50 minutes for $o^{\prime} 100$ (Table 1).

By day periodicity is less obvious, due mainly to variation in the length of the rest periods, and here the mean cycle length is $86 \mathrm{mi}$ nutes.

Table 2 summarizes the principal features of the activity pattern in C. suaveolens. The mean number of periods of activity recorded during 24 hours was 24-27. Minutes of activity summed over 24 hours totalled 325 with about $80 \%$ occurring at night.

No changes were detected in the activity pattern of $\sigma^{7} 100$ after two months in captivity (Table 3 ). After 4 months in captivity, however,

Table 1

Duration of periods of activity and rest in minutes.

Means and standard errors are given; $\mathrm{F}$ - female, $\mathrm{M}$ - male.

\begin{tabular}{lcrrrc}
\hline & & \multicolumn{2}{c}{ Active } & \multicolumn{2}{c}{ Rest } \\
& & Night & Day & Night & Day \\
\hline C. suaveolens & F 99 & $* 16.1 \pm 0.7$ & $6.5 \pm 0.5$ & $* 24.9 \pm 0.7$ & $59.8 \pm 2.3$ \\
C. russula & M 100 & $* 14.4 \pm 0.7$ & $10.2 \pm 1.2$ & $* 36.2 \pm 1.1$ & $69.0 \pm 4.2$ \\
& F 19 & $* 12.6 \pm 0.7$ & $8.7 \pm 0.5$ & $* 21.4 \pm 0.9$ & $28.1 \pm 1.6$ \\
& M 18 & $* 29.1 \pm 2.6$ & $8.2 \pm 0.4$ & $27.1 \pm 1.1$ & $29.5 \pm 1.3$ \\
\hline
\end{tabular}

* Differences between means for night and day $>2$ SE's

periods of activity by day were longer and periods of rest by night were shorter, the differences being significant. The number of periods of activity dropped from 22 to 17 , and total activity was reduced by onefifth (Table 2). The animal had become more diurnal, and over $60 \%$ of its activity now occurred by day.

\subsection{The Activity Pattern in C. russula}

The activity patterns of the two $C$. russula studied closely resemble those of the suaveolens (Fig. 2, a-b). The summed records show comparable peaks at dawn and dusk (compare Figs. la and 2a), and total activity for the 24 hours is about the same. However in russula, a much higher proportion of the activity occurs during the day, and periodicity is evident by day as well as by night. 


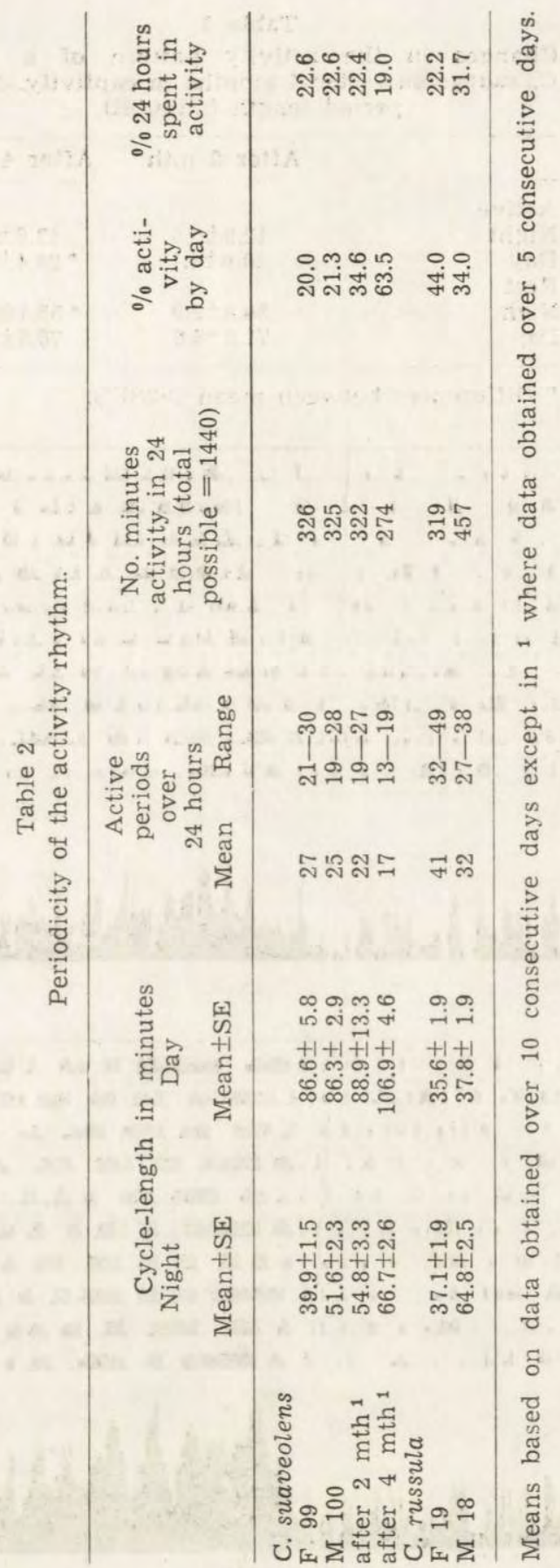


Table 3

Changes in the activity pattern of a male C. suaveolens after 4 months in captivity. Mean period length (minutes).

\begin{tabular}{lcr}
\hline & After $2 \mathrm{mth}$ & After $4 \mathrm{mth}$ \\
\hline Active & & \\
Night & $12.9 \pm 0.8$ & $12.6 \pm 0.9$ \\
Day & $10.6 \pm 1.1$ & $* 20.4 \pm 1.9$ \\
Rest & $39.8 \pm 2.9$ & $* 55.1 \pm 5.6$ \\
Night & $71.8 \pm 6.6$ & $76.5 \pm 7.5$ \\
Day & \\
\hline
\end{tabular}

* Differences between mean $>2$ SE's.
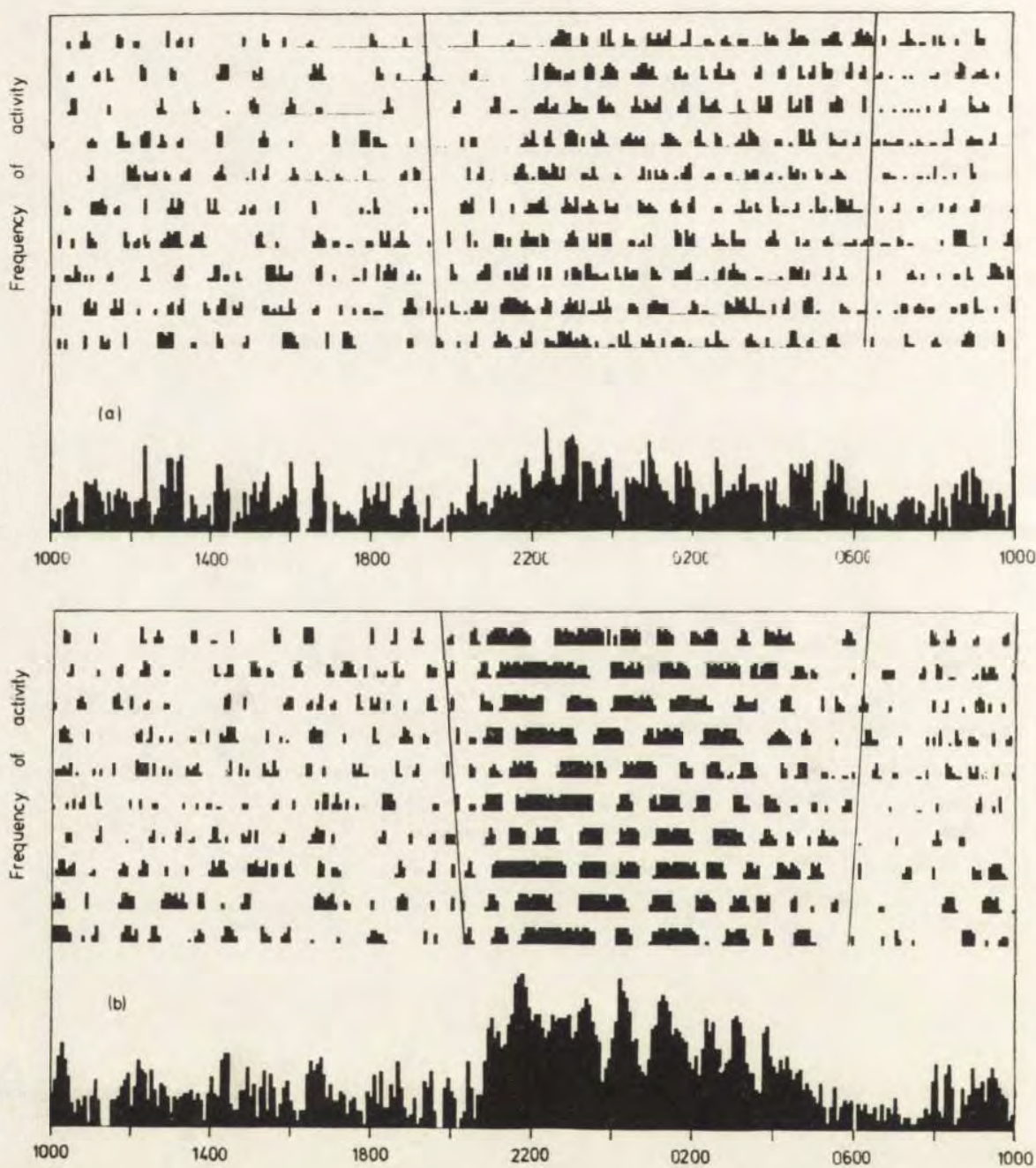

Fig. 2. Total activity recorded during 10 consecutive days (above) with summed records (below). Explanation see Fig. 1.

a. C. russula, female 19 b. C. russula, male 18 
In the $\%$ (Fig. 2a), the mean cycle length is the same by day and by night but in the $\sigma^{*}$ (Fig. 2b) the cycle is longer at night (Table 2). This is due to an increase in the lenght of the periods of activity, the periods of rest being unchanged. In the $\sigma^{*}$, the mean duration of the periods of activity is 30 minutes compared with $12-16$ minutes in the other 3 individuals, and rests of less than 5 minutes seen in the others are missing. Food consumption was similar in all 4 individuals. It was not possible to observe the animal while recording but observations made afterwards indicated that most of this activity was unconnected with feeding. Unexpectedly, the mean length of the rest periods was the same by day as by night.

\subsection{The Activity Pattern in $\mathbf{F}_{1}$ Crocidura}

Data obtained for one $F_{1}$ suaveolens and two $F_{1}$ russula during 10 consecutive days' recording showed no traces of either a short-term or a 24-hour rhythm. Minor peaks were evident in the summed records, but these were not correlated with the times of sunrise and sunset. Nearly half of the total activity occurred during the day.

\subsection{Feeding Activity in C. suaveolens}

Periods of feeding activity in $\sigma^{*} 100$ were recorded over a 10-day period, beginning as soon as observations on total activity were completed (Fig. 3). Analysis of the data shows that during 24 hours the mean number of minutes spent in visits to the food-pot was $136.1 \pm 10.3$. Visits

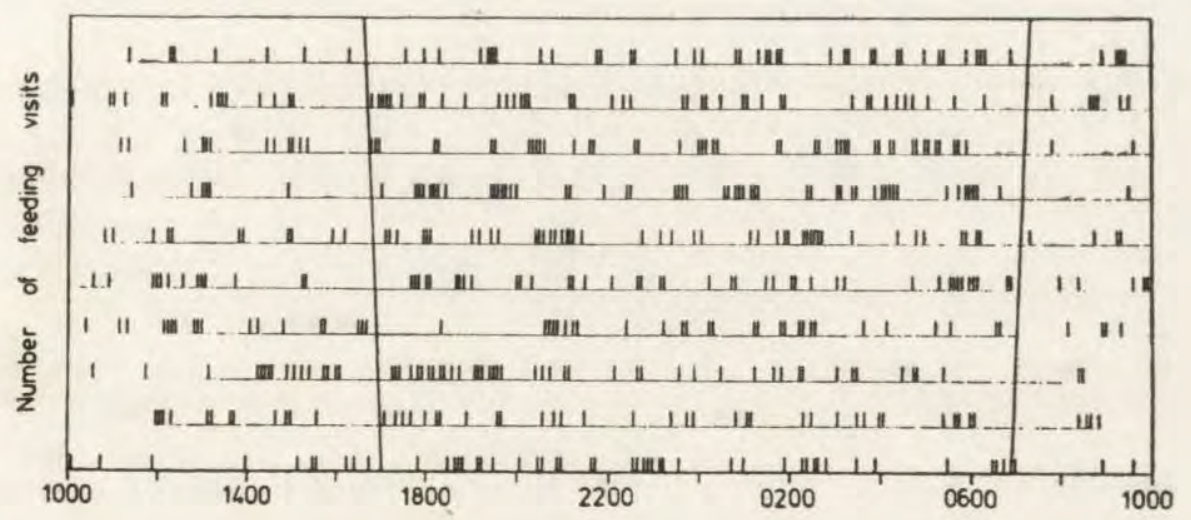

Fig. 3. Feeding activity of C. suaveolens, male 100 recorded during 10 consecutive days. Time (unit $=5^{\prime \prime}$ ) on $x$-axis, feeding visits on $y$-axis. 
during the day occupied 30 minutes or $23.4 \%$ of the total. This proportion is almost the same as the proportion of the total activity occuring by day, recorded 10 days earlier (Table 2).

The number of feeding visits recorded by day varied from $6-10$; the distribution of visits suggests that one mealworm only was eaten per visit. Over 24 hours the mean number of mealworms consumed was 37 (30-42). The mealworms weighed a total of $3.5 \mathrm{~g}$, giving a daily intake equal to one-half the animal's body weight.

\section{DISCUSSION}

These results show that Crocidura is active during both day and night. Of the two species studied, C. suaveolens is the more nocturnal with about $80 \%$ of its activity occurring at night. Among the suaveolens trapped in Jersey during 1974-76, a similar difference was found in the ratio between day and night catches ( $\mathrm{G}$ o d f re y, 1978).

The two russula were less nocturnal and $35-45 \%$ of their activity occurred by day. This difference in behaviour was reflected in the type of nest constructed in the laboratory: russula being the more diurnal usually had open, saucer-shaped nests whereas those of suaveolens were spherical with tightly-woven roofs. Too few russula have been trapped in Alderney to permit day and night catches to be compared.

In the Scilly Islands, where trapping was carried out only in June and August, C. suaveolens cassiteridum was found to be more active by day than by night (R o o d, 1965).

A short-term rhythm of activity is a prominent feature of the behaviour patterns of small rodents and insectivores in the laboratory. There is a rough correlation between cycle-length and body-size, and in the common shrew, Sorex araneus, the periodicity is about two hours (Crow croft, 1954). There is considerable evidence, however, to suggest that a short-term rhythm is well-developed only in the relatively uniform conditions of the laboratory. It is less likely to be present in the wild, particularly in predators where the food-items are often small and widely-dispersed (A s h b y, 1972).

By using radar to study activity it was possible to keep the experimental animals in bins that were relatively large and contained a thick layer of cover. Of the newly-trapped Crocidura, only a $\sigma^{\pi}$ russula showed a regular short-term cycle similar to those observed in other laboratory studies. It is suggested that the lack of a short-term cycle in the other individuals was due partly to the experimental conditions, and partly to the fact that the animals still retained the rhythms present in the wild. 
The lengthening of the cycle observed in a $\sigma^{x}$ suaveolens after 4 months in captivity lends support to this hypothesis.

In the other newly-trapped Crocidura the cycles were shorter and periodicities ranged from 35 minutes in russula to 40 or 50 minutes in suaveolens. No correlation with body-size was apparent. Cycles with a periodicity of this order were also observed in Sorex, and $\mathrm{Crow}$ c r of t (1954) suggested that they represented a feeding rhythm within the short-term cycle. Information on periods of feeding activity obtained during the present study confirm the short periodicity of the feeding rhythm in Crocidura.

Acknowledgements: This work was financed by the Trustees of the Chicago Zoological Society to whom grateful acknowledgement is made. My thanks are due to the Jersey Wildlife Preservation Trust for the provision of laboratory facilities. Dr. F. C. Flack of the Physics Department, University of Exeter, kindly loaned the radar aquipment. Ian Linn criticized a draft of this manuscript.

\section{REFERENCES}

1. Ashby K. R., 1972: Patterns of daily activity in mammals. Mamm. Rev. 1: $171-185$.

2. Crow croft P., 1974: The daily cycle of activity in British shrews. Proc. zool. Soc. Lond., 123: 715-729.

3. Crowcroft P. \& Godfrey G. K., 1958: The daily cycle of activity in two species of Sminthopsis (Marsupialia-Dasyuridae). J. Anim. Ecol. 37: 63-73.

4. Godfrey G. K., 1978: The ecological distribution of shrews (Crocidura suaveolens Pa1las, 1811 and Sorex araneus fretalis Miller, 1909) in Jersey. J. Zool., Lond., 183: (in press).

5. Loxton R. G., Raffaelii D. \& Begon M., 1975: Coprophagy and the diurnal cycle of the common shrew, Sorex araneus. J. Zool., Lond., 177: 449$-453$.

6. Pernetta J. C., 1973: The ecology of Crocidura suaveolens cassiteridum (Hinton) in a coastal habitat. Mammalia, 37: 241-256.

7. R o od J. P., 1965: Observations on the home range and activity of the Scilly shrew. Mammalia, 29: 507-516.

8. Spencer-Booth Y., 1963: A coastal population of shrews (Crocidura suaveolens cassiteridum). Proc. zool. Soc. Lond., 140:322-326.

Accepted, December 17, 1977.

Gillian K. GODFREY

\section{WZORZEC AKTYWNOSCI ZĘBIEŁKOW, BADANY ZA POMOCA RADARU}

\section{Streszczenie}

Zbadano całoksztalt aktywności zębielków: Crocidura suaveolens i C, russula. Stwierdzono, że poszczególne osobniki wykazywały aktywność przez 24 godziny 
z tym, że C. russula okazała się zwierzęciem bardziej dziennym (Tabele $1-3$ ). Wzorzec aktywności świeżo zlapanych osobników wykazuje wyraźnie zaznaczające się rytmiczne okresy aktywności pokarmowej z przeciętną długością cyłkliczną $30-50$ minut. Zębielki urodzone $w$ laboratorium były bardziej aktywne za dnia aniżeli osobniki z terenu a wzorzec ich aktywności nie wykazywal rytmu pokarmowego ani 24 godzinnego. 